\title{
Article
}

\section{Calculations for medicines management and cost efficiency}

\author{
Nuttall, Dilyse \\ Available at http://clok.uclan.ac.uk/21232/ \\ Nuttall, Dilyse ORCID: 0000-0002-0561-5229 (2016) Calculations for \\ medicines management and cost efficiency. Nurse Prescribing, 14 (6). pp. \\ 274-275. ISSN 2052-2924
}

It is advisable to refer to the publisher's version if you intend to cite from the work. 10.12968/npre.2016.14.6.274

For more information about UCLan's research in this area go to

http://www.uclan.ac.uk/researchgroups/ and search for < name of research Group>.

For information about Research generally at UCLan please go to http://www.uclan.ac.uk/research/

All outputs in CLoK are protected by Intellectual Property Rights law, including Copyright law. Copyright, IPR and Moral Rights for the works on this site are retained by the individual authors and/or other copyright owners. Terms and conditions for use of this material are defined in the policies page.

\section{CLoK}

Central Lancashire online Knowledge www.clok.uclan.ac.uk

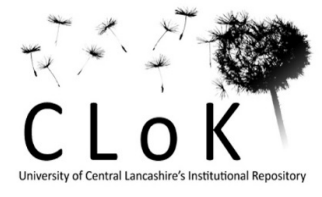




\section{Calculation Skills: Medicines Management and Cost Efficiency}

In 2013, the annual prescribing spend per person in England was $£ 142$ (Nuffield Trust, 2016a). With a population of on 54.3 million in England in 2014 (ONS, 2015), it is crucial that prescribing is appropriate and effective, with processes in place to manage this. Medicine's management is not a new concept, with the National Prescribing Centre defining it in 2002 as: 'a system of processes and behaviours that determines how medicines are used by patients and the NHS'. Primary Care Commissioning [PCC] (2012) highlighted that medicines management is not just about cost but also concerned with the development of new models of treatment to improve patient outcomes and to support adherence.

NB American billion to be used in calculation (1000 million)

Question 1

Based on the figures above, answer the following questions:

(i) Assuming the prescribing spend per person remained constant, what would have been the total prescribing spend for England in 2014 (to the nearest billion)?

(ii) PCC (2012) reported a $4.8 \%$ prescribing cost inflation in 2010. If this trend continued, what would have been the average prescribing spend per person in England in 2014 (calculate this on the known cost for 2013). Round the answer up or down to the nearest pence. You may find it easier to convert the figures to pence

(iii) If an average saving of $3 \%$ could be made to the prescribing spend per person (based on the 2013 figure) to a third of the population in England (based on the 2014 population figure), what total saving would be made?

\section{Question 2}

PCC (2012) reported that the NHS medicines bill for 2010 was $£ 12.9$ billion and that $32 \%$ of that was generated in secondary care.

(i) How much did non-secondary care medicines cost the NHS in 2010?

\section{Question 3}

One of the key influences on the overall bill for medicines is the number of items prescribed. Polypharmacy can result in a range of unwanted consequences for the patient and the service, making review an important strategy in prescribing. Nuffield Trust (2016b) identified that there were variations in the number of items prescribed per person between the four countries of the UK, with Wales averaging 24 items, England, 19, Northern Ireland, 21 and Scotland 19.

(i) Taking into account this data and the average spend per person figure identified earlier, what is the average cost per item in England (rounded up or down to nearest pence)?

(ii) Nuffield Trust (2016a) identified that the average spend per person in Scotland was $£ 176$, Northern Ireland $£ 197$ and Wales $£ 179$. What is the cost difference between the UK country with the lowest average cost per item and the one with the highest?

\section{Question 4}


Enid, aged 80 attended for a review of her medicine regimen which included 9 drugs for a range of conditions, which she received as a repeat prescription, delivered by her local pharmacy. It was discovered that she had not taken the Captopril 12.5mg tablets (supplied 56 tablets monthly at a cost of $£ 2.80^{\star}$ ) for 8 months as they made her feel dizzy. She had stopped taking the Omeprazole $20 \mathrm{mg}$ capsules (supplied 28 capsules monthly at a cost of £13.92*) after having a hernia repair 6 months previously and only used the emollient cream (supplied one $500 \mathrm{ml}$ bottle monthly at a cost of $£ 5.50^{\star}$ ) infrequently when her preferred body butter ran out (leaving 5 bottles unused at home).

${ }^{*}$ Costs based on BNF 70

Assuming that these treatments were no longer appropriate for Enid and no alternatives found to be necessary:

(i) What was the total cost of the unused medicines?

(ii) Assuming Enid's remaining six medicines totalled a cost of $£ 9.50$ per month, what percentage saving (based on the cost of the nine medicines) has been made by stopping these three unused medicines from being prescribed (rounded up or down to the nearest pence)?

\section{Answers}

\section{Question 1}

(i) $\quad £ 142 \times 54300000=£ 7,710,600000$ (8 billion when expressed as nearest billion)

(ii) $2013100 \%$ of the cost $=£ 142$

$$
\begin{aligned}
& 1 \%=£ 1.42 \\
& 4.8 \%=142 p \times 4.8=682 p / £ 6.82
\end{aligned}
$$

2014 cost $=£ 142+£ 6.82=£ 148.82$

(iii) $3 \%$ saving $=1.42 \times 3=£ 4.26$ per person

$3^{\text {rd }}$ of the population $=54.3$ million $\div 3=18.1$ million

$18100000 \times 4.26=£ 77,106,000$

\section{Question 2}

(i) $12,900,000,000 \div 100=129,000,000$

$32 \times 129,000,000=4,128,000,000$

$12,900,000,000-4,128,000,000=8,772,000,000$

Non-secondary care cost $=£ 8772000$

\section{Question 3}

(i) Cost per person $=£ 142$, no. Items $=19$. Average cost per item $=142 \div 19=£ 7.47$

(ii) England $+£ 7.47$

Scotland $=£ 176 \div 19=£ 9.26$

Wales $=£ 179 \div 24=£ 7.46$

Northern Ireland $=£ 197 \div 21=£ 9.38$ 
Highest is $\mathrm{NI} £ 9.38$, lowest is Wales $£ 7.46$, difference is $9.38-7.46=£ 1.92$

\section{$\underline{\text { Question } 4}$}

(i) Captopril $8 \times £ 2.80=£ 22.40$

Omeprazole $6 \times £ 13.92=£ 83.52$

Emollient $5 \times £ 5.50=£ 27.50$

Total $=£ 133.42$

(ii) Monthly wastage $=2.80+13.92+5.50=22.22$

Monthly cost of remaining drugs + monthly wastage $=$ original monthly cost

$9.50+22.22=£ 31.72$

$1 \%=3172 \div 100=31.72$

$2222 \div 31.72=70 \%$ (rounded down)

\section{$\underline{\text { References }}$}

Duerden, Avery \& Payne (2014) Polypharmacy and Medicines Optimisation, Making it Safe and Sound, available at:

http://www.kingsfund.org.uk/sites/files/kf/field/field publication file/polypharmacy-andmedicines-optimisation-kingsfund-nov13.pdf

*Joint Formulary Committee (2015) British National Formulary 70 (September 2015), London: BMA \& RPSGB

National Prescribing Centre (2002) Medicines Management Services - Why are they Important? Liverpool: NPC

Nuffield Trust (2016a) Annual Prescribing Spend per Person in the UK, available at: http://www.nuffieldtrust.org.uk/data-and-charts/prescribing-spend-person-uk

Nuffield Trust (2016b) Prescription Items Dispensed per Person in the UK, available at: http://www.nuffieldtrust.org.uk/data-and-charts/number-prescription-items-dispensed-person$\underline{\mathrm{uk}}$

Office of National Statistics (2015) Overview of the UK Population, available at:

http://www.ons.gov.uk/ons/rel/pop-estimate/population-estimates-for-uk--england-and-wales-scotland-and-northern-ireland/mid-2014/sty---overview-of-the-uk-population.html

Primary Care Commissioning (2012) CCG Authorisation: The Role of Medicnes Management, available at: http://www.pcc-

cic.org.uk/sites/default/files/articles/attachments/ccg authorisation -

the role of medicines management may 2012v1 0.pdf 